University of Nebraska - Lincoln

DigitalCommons@University of Nebraska - Lincoln

Faculty Publications from the Harold W. Manter Laboratory of Parasitology

1999

\title{
Absence of Tuberculosis in Free-Ranging Deer in Nebraska
}

David J. Steffen

University of Nebraska-Lincoln, dsteffen1@unl.edu

David W. Oates

Nebraska Game and Parks Commission

Mauritz C. Sterner

University of Nebraska-Lincoln

Vickie L. Cooper

University of Nebraska-Lincoln

Follow this and additional works at: https://digitalcommons.unl.edu/parasitologyfacpubs

Part of the Parasitology Commons

Steffen, David J.; Oates, David W.; Sterner, Mauritz C.; and Cooper, Vickie L., "Absence of Tuberculosis in Free-Ranging Deer in Nebraska" (1999). Faculty Publications from the Harold W. Manter Laboratory of Parasitology. 673.

https://digitalcommons.unl.edu/parasitologyfacpubs/673

This Article is brought to you for free and open access by the Parasitology, Harold W. Manter Laboratory of at DigitalCommons@University of Nebraska - Lincoln. It has been accepted for inclusion in Faculty Publications from the Harold W. Manter Laboratory of Parasitology by an authorized administrator of DigitalCommons@University of Nebraska - Lincoln. 


\section{Absence of Tuberculosis in Free-Ranging Deer in Nebraska}

David J. Steffen, ${ }^{1}$ David W. Oates, ${ }^{2}$ Mauritz C. Sterner $, 2,3$ and Vickie L. Cooper, ${ }^{1}{ }^{1}$ Veterinary Diagnostic Laboratory, University of Nebraska, Lincoln Nebraska 68583-0907, USA; ${ }^{2}$ Genetics and Forensics Analysis Laboratory, Nebraska Game and Parks Commission, Lincoln, Nebraska 68503-0370, USA, ${ }^{3}$ Harold W. Manter Laboratory of Parasitology, 529-W Nebraska Hall, University of Nebraska, Lincoln, Nebraska 68588-0514, USA.

ABSTRACT: Lymph nodes from 271 whitetailed deer (Odocoileus virginianus) and mule deer (Odocoileus hemionus) in Nebraska (USA) were examined microscopically for tuberculoid lesions. Lymph nodes lesions in at least one node were found in 12 deer. Lesions were examined with Zeihl-Neelson acid fast stains and by polymerase chain reactions using $M$. bovis specific probes. No evidence of tuberculosis was found. The small granulomatous lesions were likely caused by other bacteria.

Key words: Lymph nodes, Mycobacterium bovis, Odocoileus virginianus, survey, tuberculosis, white-tailed deer.

Activities of wildlife agencies translocating wild populations of ungulates to replenish animals in historic ranges and reduce populations of ungulates in national parks and urban areas causes growing concern among wildlife biologists regarding the accidental translocation of diseased animals (Lothian, 1981; Jones and Witham, 1990). Mycobacterium bovis infections are increasingly recognized as a problem in farmed deer populations and have been reported in wild deer (Friend et al., 1963; Ryan et al., 1995). Recent surveys of white-tailed deer (Odocoileus virginianus) in Michigan (USA) found a 5\% prevalence of M. bovis (Schmitt et al., 1997). This presence and the potential for spread of $M$. bovis threaten livestock disease control programs and could impact human health. The present study was initiated to evaluate white-tailed and mule (Odocoileus hemionus) deer populations in Nebraska (USA) and draw some inferences regarding potential disease prevalence.

Twenty-eight locker plants in Nebraska were contacted by the Nebraska Game and Parks Commission (Lincoln, Nebraska) and all agreed to save the heads of deer brought to them for processing by hunters during 1996 rifle deer season. The county of origin of the deer could be traced by the tag placed on the deer at time of harvest. The heads were frozen and delivered to the Veterinary Diagnostic Center (University of Nebraska, Lincoln, Nebraska) where lymph nodes were collected for examination.

Cranial lymph nodes in 271 adult deer harvested in Nebraska during November of 1996 were examined for tuberculosis. Parotid, submandibular, sublingual and retropharyngeal nodes were collected from each deer, fixed in $10 \%$ buffered formalin and processed for histologic examination. Sections were stained with hematoxylin and eosin. Sections with lesions were additionally stained with Zeihl-Neelson acid fast and Brown and Bren gram stain techniques (Luna, 1968). Lymph nodes with lesions were submitted to the National Animal Disease Center (Ames, Iowa, USA) for polymerase chain reaction (PCR) analysis using $M$. bovis specific probes (Miller et al., 1997). The primers amplified a 123-base pair fragment of isolate IS6110 that is specific for Mycobacterium tuberculosis complex including $M$. tuberculosis and M. bovis.

Following the 1996 deer harvest 353 deer heads from 72 of 93 counties were examined. Of the total number examined 257 were adult white-tailed deer and 47 were adult mule deer. Thirty-three were not examined because of unavailability of sufficient nodes due to gunshot injury or removal the nodes during skinning and/or head removal.

Examination of lymph nodes removed from adult deer in Nebraska revealed gross lesions including yellow discoloration and softening in only three of the lymph nodes examined. Lesions were observed microscopically in 12 cranial lymph nodes 


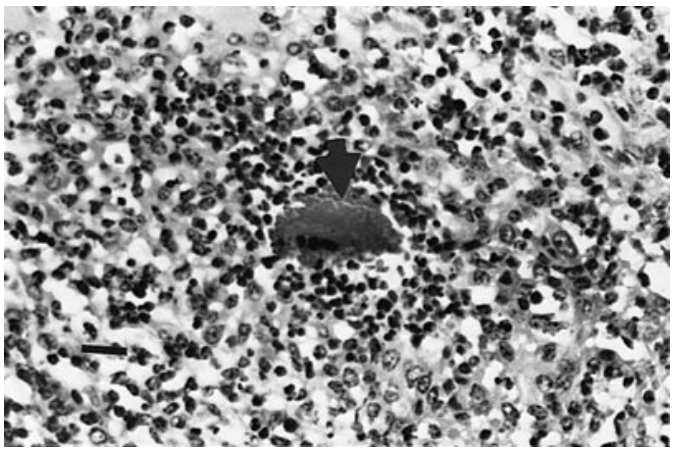

Figure 1. Club colony (arrow) within a chronic active pyogranulomatous lesion within a lymph node from a white-tailed deer in Nebraska H\&E. Bar = $80 \mu \mathrm{m}$.

of the $271(3 \%)$ deer examined. Lesions were identified in four mule deer and eight white-tailed deer from 10 counties scattered throughout the state. Cranial lymph nodes from one deer had severe medullary fibrosis with an occasional small cluster of multinucleated giant cells and macrophages surrounding mineralized debris. Lymph nodes of three deer had small mineralized foci surrounded by a rim of epithelioid macrophages; one of these foci had a central radiating eosinophilic structure. Two deer had multifocal granulomas consisting of epithelioid macrophages arranged as irregular sheets within the cranial nodes. These macrophages contained granular and, in one case, refractive material. The remaining six deer had nodes with focal (three deer) or multifocal coalescing (three deer) neutrophilic and histiocytic infiltrates (Fig. 1). Four of the six cases had centrally located radiating eosinophilic rods (Fig. 1). No acid fast or other bacteria were demonstrated within the lesions stained with acid fast and gram staining techniques. No mycobacterium specific 123 base pair fragments of PCR product were detected from the 12 blocks containing lesions submitted to the National Animal Disease Center.

Lesions recorded in two of the deer from Nebraska were pyogranulomatous and resembled those described previously for tuberculosis (Ryan and Saari, 1992). In four of six deer with pyogranulomatous change, radiating eosinophilic rods (club colonies) were present centrally and suggested a cause other than tuberculosis. The negative acid fast stains and abscence of detectable PCR product also suggested an etiology other than tuberculosis. The etiology of these lymph node lesions requires studies which include collection of fresh specimens for culture. Lymph node lesions were most often small, chronic and not evident grossly. It is suspected that lesions are extensions of past oral infections and the organisms involved to be of limited consequence to deer populations. Actinomycete sp. and Actinobacillus sp. infections have been associated with the formation of the eosinophilic radiating central "club colony" structures in other species and may be responsible for the lesions reported here. These organisms are common in the oral cavity of many ruminant species.

Mycobacterium bovis infections were reported in a four county area of Michigan (Schmitt et al., 1997). Fifteen of 16 reported cases had grossly visible lesions in the cranial lymph nodes. Deer and elk tend to have mycobacterial lesions which are suppurative to pyogranulomatous in nature and containing acid fast staining bacilli (Rhyan and Saari, 1992). We did not find these in our survey.

The higher $(5 \%)$ prevalence reported in Michigan may have been due partially to local residents feeding the deer, creating an artificially high population density and the presence of infected cattle from a local herd. Local pockets of infection could exist or develop in any state; therefore hunters, check station personnel, and meat processors need to remain vigilant investigating anything abnormal found.

We thank P. Oates, E. Oates, M. Oates, E. Boyd, S. O’Hare, K. Hams, A. Doster, and J. Erickson for assistance and A. Jenny, J. Miller, and the National Veterinary Services Laboratory for PCR analysis. This is a contribution of Federal Aid in Wildlife 
Restoration, Project W-85-R and a contribution of the Nebraska Agricultural Research Division, University of Nebraska.

\section{LITERATURE CITED}

Friend, M., E. T. Kroll, and H. Gruft. 1963. Tuberculosis in wild white-tailed deer. New York Fish and Game Journal 10: 118-123.

Jones, J. M., AND J. H. Witham. 1990. Post-translocation survival and movements of metropolitan white-tailed deer. Wildlife Society Bulletin 18: 434-441.

Lothian, W. F. 1981. A history of Canada national parks. Volume IV. Ministry of Environment, Parks of Canada, Ottawa, Ontario, Canada, 155 pp.

LunA, L. G.. 1968. Manual of histologic staining methods of the Armed Forces Institute of Pathology, 3rd Edition. McGraw Hill, New York, New York, 258 pp.
Miller, J. A. Jenny, J. Ryan, C. SaAri, and D. SUAREZ. 1997. Detection of Mycobacterium bovis in formalin-fixed, paraffin-embedded tissue of cattle and elk by PCR amplification of an IS6110 sequence specific for Mycobacterium tuberculosis complex organisms. Journal of Veterinary Diagnostic Investigation 9: 244-249.

Ryan, J. C., AND D. A. SAari. 1995. A comparative study of the histologic features of tuberculosis in cattle, fallow deer (Dama dama), sika deer (Cervus nippon), red deer and elk (Cervus elaphus). Veterinary Pathology 32: 215-220.

Schmitt, S. M., S. D. Fitzgerald, T. M. Cooley, C. S. Bruning-Fann, L. Sullivan D. Berry, T. Carlson, R. B. Minnis, J. B. Payer, and J. SiKARSKIE. 1997. Bovine tuberculosis in free-ranging white-tailed deer from Michigan. Journal of Wildlife Diseases 33: 749-758.

Received for publication 13 May 1998. 